\title{
PERBANDINGAN GAYA MENGAJAR KOMANDO DENGAN GAYA MENGAJAR DISKOVERI TERHADAP HASIL BELAJAR MENEMBAK (SHOOTING) DALAM PEMBELAJARAN BOLA BASKET
}

\author{
Harry Wibowo Sampurno ${ }^{1}$, Suryadi² \\ ${ }^{1}$ Program Studi Pendidikan Jasmani, Kesehatan dan Rekreasi, STKIP Situs Banten, \\ ${ }^{2}$ Program Studi Pendidikan Bahasa Inggris, STKIP Situs Banten, \\ Jln. Raya Cipocok Kota Serang Banten \\ 1e-mail: satriapiningit69@yahoo.com
}

\begin{abstract}
Abstrak
Tujuan penelitian ini yaitu untuk memperbaiki dan meningkatkan kualitas pembelajaran shooting. Metode penelitian yang digunakan adalah metode eksperimen, dengan desain penelitian menggunakan posttest only control group design. Sampel penelitian sebanyak 40 orang siswa puteri, yang secara random dan proposional dibagi menjadi dua kelompok yaitu kelompok A dan Kelompok B. Hasil penelitian dibuktikan dengan distribusi $\mathrm{t}$ tabel pada taraf signifikansi $\alpha=0.05$ dengan $\left(\mathrm{n}_{1}+\mathrm{n}_{2}-2\right)=38$, harga $\mathrm{t}(0.95)=1,68$, sedangkan $\mathrm{t}$ hitung hasil pengujian $=2.8$. Maka dengan demikian $\mathrm{t}$ hitung $>\mathrm{t}$ tabel maka Ho ditolak. Hal ini dapat ditafsirkan bahwa gaya mengajar diskoveri $\left(\mathrm{x}^{-}=10.05, \mathrm{~s}=6.19\right)$ memberikan pengaruh lebih besar dibandingkan dengan gaya mengajar komando $\left(\mathrm{x}^{-}=7.9, \mathrm{~s}=4.87\right)$ terhadap hasil belajar shooting bolabasket. Dari hasil penelitian tersebut disimpulkan bahwa dengan mengajar gaya diskoveri meningkatkan hasil belajar shooting dalam pembelajaran bolabasket daripada mengajar dengan gaya komando.
\end{abstract}

Kata kunci: gaya mengajar, komando, diskoveri, shooting bolabasket

\begin{abstract}
The purpose of this study is to improve and improve the quality of shooting learning. The research method used was an experimental method, with the research design using posttest only control group design. The research sample of 40 female students, which were randomly and proportionally divided into two groups, namely group A and group $B$. The results of the study were evidenced by the distribution of t tables at the significance level $\alpha=0.05$ with $\left(n_{1}+n_{2}-2\right)=38$, the price of $t(0.95)=1.68$, while t arithmetic test results $=2.8$. So thus t arithmetic $>$ T table then Ho is rejected. It can be interpreted that the style of teaching cover $\left(x^{-}=10.05, s=6.19\right)$ gives a greater influence than the command teaching style $\left(x^{-}=7.9, s=4.87\right)$ on the learning outcomes of shooting basketball. From the results of the study it was concluded that teaching discovers style improves learning outcomes in shooting in basketball learning rather than teaching in command style.
\end{abstract}

Keywords: teaching style, command, discovers, basketball

\section{PENDAHULUAN}

Permainan bolabasket merupakan salah satu cabang olahraga yang banyak dimainkan oleh masyarakat, di samping olahraga lain seperti sepakbola dan bolavoli. Banyaknya masyarakat yang bermain bolabasket di antaranya disebabkan oleh aturan permainannya sederhana, bisa dimainkan oleh anak-anak, remaja, tua, 
muda, perempuan dan lelaki, lapangannya tidak terlalu sulit, masal, dan mengandung unsur-unsur permainan. Permainan bolabasket juga mengajarkan toleransi, sportifitas, fair play, mendidik, kompetitif, menghibur dan menyehatkan melalui aktivitas fisik sehingga kebugaran jasmani bisa ditingkatkan. Gerakan dalam permainan bolabasket terdiri dari gabungan unsur-unsur gerak yang terangkai dengan rapi, sehingga menunjukkan suatu permainan yang meriah. Tujuan bermain bolabasket adalah untuk mendapat nilai (skor) dengan memasukkan bola ke dalam keranjang lawan dan mencegah tim lawan melakukan hal serupa (Margono, 2010). Melalui permainan bolabasket, seluruh potensi dari seluruh aspek yang diajarkan dalam permainan ini diyakini dapat berpotensi untuk dapat ditumbuh kembangkan. Sampai batas-batas tertentu, apalagi jika kegiatan pembelajaran pendidikan jasmani tersebut diintervensi oleh guru Penjas yang memiliki kompetensi sebagai tenaga pendidik. Maka nilai-nilai pendidikan yang terkandung dalam permainan bolabasket tersebut akan lebih dikembangkan lagi secara lebih luas.

Dengan keyakinan terhadap nilai-nilai pendidikan yang terkandung dalam permainan bolabasket, maka tidak salah pada saat ini permainan bolabasket menjadi salah satu cabang olahraga yang masuk ke dalam struktur kurikulum pendidikan jasmani mulai dari SD, SMP, dan SMA, bahkan diajarkan di beberapa perguruan tinggi, sehingga permainan bolabasket menjadi suatu kewajiban dalam pembelajaran pendidikan jasmani.

Dalam konteks permainan atau bermain, tujuan bermain bolabasket adalah (1) memasukkan bola ke dalam keranjang lawan dan (2) mencegah lawan untuk memasukkan bola ke keranjang sendiri. Dengan demikian ada dua hal persoalan penting yang dapat menunjang keberhasilan bermain bolabasket yaitu bagaimana agar dapat memasukkan bola ke dalam keranjang lawan sebanyak-banyaknya dan bagaimana agar lawan tidak dapat memasukkan bola ke keranjang sendiri.

Memperhatikan konsep tujuan permainan bolabasket maka teknik shooting merupakan keterampilan teknik yang inti untuk dipelajari. Sehingga wajar jika dalam pembelajaran bolabasket keterampilan teknik shooting dijadikan fokus utama pembelajaran. Bahkan jika dilihat dari motivasi siswa berlatih, shooting 
merupakan salah satu keterampilan teknik yang paling digemari terutama oleh siswa yang baru belajar bolabasket. Dengan demikian maka keterampilan teknik shooting harus dipelajari seorang pemain bolabasket karena keterampilan shooting yang baik sering menjadi penentu kemenangan dalam sebuah pertandingan.

Melalui berbagai teknik, metode, dan strategi pembelajaran yang digunakan oleh guru, keterampilan shooting harus menjadi fokus utama di dalam pembelajaran bolabasket dalam konteks pendidikan Permasalahan yang nampak di dalam pembelajaran permainan bolabasket, khususnya pembelajaran shooting di antaranya sarana dan prasarana yang meliputi keterbatasan ring basket, ukuran ketinggian ring basket, perbedaan secara genetika antara kekuatan putra dan putri dalam bermain bolabasket. Kemudian kompetensi guru pendidikan jasmani terhadap penguasaan pendekatan, strategi, dan metode pembelajaran bolabasket.

Hampir di semua lapangan bolabasket yang ada, hanya terdapat dua buah ring (basket) yang ada di belakang garis akhir lapangan permainan bolabasket, padahal tujuan bermain adalah memasukkan bola sebanyak-banyaknya ke ring lawan, seperti halnya kebutuhan ring bolabasket untuk sesuatu pertandingan resmi, bukan untuk pembelajaran. Jarang sekali ada lapangan bolabasket yang dilengkapi dengan jumlah ring basket yang memadai dengan jumlah siswa. Ukuran ketinggian ring basket disesuaikan dengan karakteristik fisik anak, misalnya tinggi rendahnya kedudukan ring basket. Seyogyanya dengan satu kelas yang diasumsikan 40 siswa yang terdiri atas putera dan puteri, minimal harus terdapat 20 ring untuk dapat menciptakan suasana pembelajaran shooting di sekolah dengan sangat efektif.

Di samping jumlah ring bolabasket yang kurang sesuai dengan rasio jumlah siswa, juga ukuran ketinggian bolabasket yang kurang sesuai dengan karakteristik siswa, terutama kekuatan siswa di SMP atau SMA/SMK sangat bervariasi, apalagi terdapat putera dan puteri yang secara genetik berbeda. Masih banyak siswa puteri yang tidak memiliki kekuatan untuk melakukan lemparan atau shooting setinggi ring seperti halnya ring yang terdapat di peraturan bolabasket.

Berlatih atau belajar memasukkan bola ke dalam keranjang harus merupakan fokus utama dalam permainan bolabasket, namun faktanya masih banyak guru pendidikan jasmani di Indonesia kurang memahami tujuan tersebut. 
Hal ini bisa dilihat bahwa guru kurang memanfaatkan alokasi waktu yang disediakan ditambah dengan jumlah siswa yang terlalu banyak, dan biasanya guru hanya memberikan bola kepada siswa, kemudian membiarkan siswa bermain bolabasket dengan tidak ada konsep pembelajarannya.

Gaya mengajar yang dilakukan oleh guru dalam praktik pendidikan jasmani cenderung tradisional khususnya pembelajaran shooting. Model dan metodemetode praktik dipusatkan pada guru, dimana pada saat belajar shooting, kegiatan pembelajaran masih banyak yang berorientasi terhadap penguasaan keterampilan teknik dengan melakukan latihan shooting dengan cara-cara tertentu. Sementara dalam pembelajaran bolabasket memerlukan kreatifitas tentang cara memasukkan bola ke dalam keranjang secara bervariasi. Latihan-latihan tersebut hampir tidak pernah dilakukan oleh anak sesuai dengan inisiatif sendiri. pada intinya model dan metode-metode praktik dipusatkan pada guru hanya pada penguasaan teknik dengan cara-cara shooting yang baku, sementara model dan metode praktik yang terfokus pada siswa) lebih kepada mengembangkan daya pikir siswa terhadap caracara memasukkan bola yang disesuaikan dengan situasi dan kondisi.

Shooting merupakan keterampilan gerak yang memiliki karakteristik dominan keterampilan terbuka (open skill), keterampilan diskrit (discrete skill), dan keterampilan kasar (groos skill). Dalam pelaksanaan permainan bolabasket yang sebenarnya, keterampilan shooting banyak dipengaruhi oleh situasi dan kondisi saat permainan berlangsung. Teknik dasar shooting yang baku kadang kala tidak dapat dilaksanakan karena adanya lawan yang memblok, jarak dan sudut ketika ingin melakukan shooting akan selalu berubah karena lawan yang menjaga, yang terpenting dari keterampilan shooting dalam permainan bolabasket yang sebenarnya adalah bola masuk ke dalam ring basket. hal ini sesuai dengan tujuan utama permainan bolabasket. Shooting atau menembak merupakan suatu keterampilan dalam menyerang yang paling ampuh dan terpenting di antara berbagai keterampilan teknik menyerang (Rubiana, 2017). Shooting sangat penting dalam suatu permainan bolabasket dan menentukan tim tersebut untuk meraih point atau tidak karena sebenarnya untuk dapat menjadi penembak yang mahir diperlukan ketekunan dalam latihan dan peningkatan latihan secara tepat 
(Yulidasari, 2015). Kesalahan teknik dasar shooting banyak terjadi pada setiap indikator awalan seperti; (1) Kaki dibuka selebar bahu dan lutut ditekuk dan badan sedikit condong,(2) Tangan kanan memegang bola kemudian letakan di atas kepala dan di depan dahi,(3) Siku ditekuk membentuk sudut 90 derajat,(4) Lihat target,(5) Melakukan tolakan dengan menggunakan kedua kaki, (6) Bola ditembakan ke keranjang basket dengan gerakan siku,badan dan lutut diluruskan secara berirama dan (7) Telapak tangan kebawah saat bola terlepas (Majid \& Roesdiyanto, 2018).

Gaya mengajar komando merupakan gaya mengajar yang berpusat pada guru. Pembelajarannya menekankan pada keseragaman gerak, standar baku yang telah ditentukan, dengan kaidah-kaidah anatomi gerak, biomekanika yang seragam. Jika diterapkan pada pengajaran shooting yang memiliki karakteristik keterampilan tersebut diatas, nampaknya kurang cocok dilaksanakan karena tidak sesuai dengan karakteristik permainan bolabasket yang sebenarnya. Oleh karena itu, diduga dalam prakteknya siswa akan terpaku pada suatu teknik standar yang baku yang telah diajarkan secara seragam. Siregar (2019) menyatakan bahwa unsur-unsur khas dalam pembelajaran menggunakan gaya komando yaitu: (1) semua keputusan dibuat oleh guru, (2) menuruti petunjuk dan melaksanakan tugas adalah merupakan kegiatan utama siswa, (3) menghasilkan tingkat kegiatan yang tinggi, (4) membuat siswa merasa terlibat dan termotivasi, (5) mengembangkan perilaku disiplin, karena harus mentaati prosedur yang telah ditetapkan. Menurut Husdarta (2013: 31) "gaya mengajar komando bertujuan mengenalkan pada siswa untuk melakukan tugas gerak secara akurat dan dalam waktu yang singkat siswa harus mengikuti segala intruksi yang disampaikan oleh guru”. Gaya komando adalah pendekatan mengajar yang paling bergantung pada guru (Lutan, 2000). Gaya mengajar komando dengan sedikit komunikasi, dimana pelatih cukup mengatakan ini benar dan ini salah pada siswi selama proses latihan, dan menekankan banyak kesempatan siswa melakukan pengulangan gerakan selama latihan, hal ini cocok untuk siswa yang sudah menguasai sebuah gerakan atau sudah lancar dalam melakukan sebuah teknik (siswa pada fase asosiatif) dalam belajar gerak (Nurhidayah dan Sukoco, 2015). Sedangkan, gaya mengajar diskoveri dapat membantu siswa belajar membuat suatu kesimpulan terhadap suatu gerakan 
shooting dilakukan pada saat situasi dan kondisi yang berubah-ubah. Hal ini sesuai dengan karakteristik permainan bolabasket yang sebenarnya. Dengan penerapan gaya diskoveri, siswa diberikan kebebasan sendiri untuk memutuskan kapan shooting dilakukan, bagaimana teknik gerak shooting dilakukan (saat dijaga oleh lawan yang selalu berubah), jarak dan sudut yang selalu berubah karena lawan yang menjaga. Memperhatikan situasi dan kondisi diatas, penerapan gaya mengajar diskoveri dalam pengajaran shooting, nampaknya cocok digunakan untuk melatih teknik shooting dalam situasi permainan bolabasket yang sebenarnya. Berdasarkan pendapat Sugiarto (2019) aspek terpenting dalam shooting adalah menempatkan bola pada ring, karena kesempatan menembak terjadi dimana pun dan siapa pun di lapangan, maka atlet harus memiliki variasi dan kreatifitas dalam permainan bola basket. Menurut Abidin (2014: 175) Discovery didefinisikan sebagai proses pembelajaran yang terjadi bila siswa disajikan materi pembelajaran yang masih bersifat belum tuntas atau belum lengkap sehingga menuntut siswa menyingkapkan beberapa informasi yang diperlukan untuk melengkapi materi ajar tersebut. Penerapan gaya mengajar discovery dapat membuat siswa lebih berperan aktif, bekerjasama, berani untk bertanya, dan dapat menyelesaikan masalah secara bersama dalam mengikuti pembeljaran dan motivasi siswa untuk mengikuti pembelajaran lebih baik, dengan begitu pembelajaran tidak hanya di ikuti oleh siswa yang sudah bisa saja tetapi semua siswa berperan dalam pembelajaran (Singgih, 2019).

Gaya mengajar yang dilakukan oleh guru dalam praktik pendidikan jasmani cenderung tradisional khususnya pembelajaran shooting. Model dan metodemetode praktik dipusatkan pada guru. Pada saat belajar shooting, kegiatan pembelajaran masih banyak yang berorientasi terhadap penguasaan keterampilan teknik dengan melakukan latihan shooting dengan cara-cara tertentu. Sementara dalam pembelajaran bolabasket diperlukan kreativitas tentang cara memasukkan bola ke dalam keranjang secara bervariasi. Latihan-latihan tersebut hampir tidak pernah dilakukan oleh anak sesuai dengan inisiatif sendiri. Pada intinya model dan metode-metode praktik dipusatkan pada guru hanya pada penguasaan teknik dengan cara-cara shooting yang baku, sementara model dan metode praktik yang 
terfokus pada siswa lebih kepada mengembangkan daya pikir siswa terhadap caracara memasukkan bola yang disesuaikan dengan situasi dan kondisi.

Berdasarkan permasalahan tersebut, maka penelitian ini bertujuan untuk menemukan ada tidaknya perbedaan hasil belajar gaya mengajar komando dengan gaya mengajar diskoveri terhadap belajar shooting dalam pembelajaran bolabasket.

\section{METODE}

Metode yang digunakan adalah metode eksperimen. Metode eksperimen dapat diartikan sebagai metode penelitian yang digunakan untuk mencari pengaruh perlakuan (treatment) tertentu terhadap yang lain dalam kondisi yang terkendalikan (Sugiyono, 2012: 80). Sampel dalam penelitian ini adalah siswi kelas XI SMK Pelita Bandung dengan jumlah sampel yang gunakan sebanyak 40 siswi, yang didapat dari perhitungan 20 persen dari total populasi penelitian sebanyak 205 siswa.

Instrumen yang digunakan dalam penelitian ini adalah tes memasukkan bola ke dalam ringbasket (Nurhasan, 2007: 240). Tujuan dari tes ini yaitu untuk mengukur keterampilan (penguasaan) teknik dasar shooting bolabasket. Desain yang digunakan dalam penelitian ini adalah posttest only control group design yaitu penelitian eksperimen yang membandingkan dua kelompok yang diberi perlakuan yang berbeda, akhir dari eksperimen ini diberikan tes shooting dengan menggunakan instrumen yang sama (Campbell, D.T \& Stanley J.C, 1966: 25). Kelompok pertama diberi perlakukan keterampilan shooting dengan gaya mengajar komando dan kelompok kedua diberi perlakuan keterampilan shooting dengan gaya mengajar diskoveri.

\section{HASIL DAN PEMBAHASAN}

Data yang diperoleh dari hasil penelitian dapat dideskripsikan seperti pada Tabel 1. 
Tabel 1 Data Hasil Penelitian

\begin{tabular}{ccc}
\hline & Kelompok A & Kelompok B \\
\hline Jumlah Data & 20 & 20 \\
Rata-Rata & 7.9 & 10.05 \\
Standar Deviasi & 4.87 & 6.19 \\
\hline
\end{tabular}

Tabel 2 Hasil Pengujian Normalitas Liliefors Kedua Kelompok

\begin{tabular}{lcccc}
\hline \multicolumn{1}{c}{ Kelompok } & n & Lhitung & Ltabel & Kesimpulan \\
\hline $\begin{array}{l}\text { Pembelajaran dengan gaya } \\
\text { mengajar Komando }\end{array}$ & 20 & 0.916 & 0.190 & Normal \\
$\begin{array}{l}\text { Pembelajaran dengan gaya } \\
\text { mengajar Diskoveri }\end{array}$ & 20 & 0.807 & 0.190 & Normal \\
\hline
\end{tabular}

Tabel 3 Hasil Uji Bartlett Kedua Kelompok

\begin{tabular}{llll}
\hline \multicolumn{1}{c}{ Kelompok } & F hitung & F $_{\text {tabel }}$ & Kesimpulan \\
\hline $\begin{array}{l}\text { Gaya Mengajar Komando dan Gaya } \\
\text { Mengajar Diskoveri }\end{array}$ & 0.475 & 3.840 & Homogen \\
\hline
\end{tabular}

Berdasarkan Tabel 2 nilai kritis L untuk Liliefors pada taraf nyata $\alpha=0.05$ dapat diketahui $\mathrm{L}_{\text {tabel }}$ kedua kelompok adalah 0.190. Nilai Lo dari kelompok pembelajaran dengan gaya mengajar komando $=0.916$ dan Lo dari kelompok pembelajaran dengan gaya mengajar diskoveri $=0.807$, maka dapat dilihat pada Tabel 3 nilai Lo kedua kelompok tersebut lebih kecil dari nilai Ltabel. Dengan demikian dapat disimpulkan bahwa sampel penelitian berasal dari populasi yang berdistribusi normal. Berdasarkan tabel harga kritik Chi Kuadrat pada taraf nyata $\alpha=0.05$ dapat diketahui $F_{\text {tabel }}$ adalah 3.840 sedangkan $F_{\text {hitung dari kelompok }}$ pembelajaran dengan gaya komando dan gaya mengajar diskoveri adalah 0.475. Maka dapat pada Tabel 3 nilai $F_{\text {hitung }}$ lebih kecil dari $F_{\text {tabel. }}$. Dengan demikian dapat disimpulkan bahwa sampel penelitian berasal dari populasi yang homogen. 
Setelah diuji semua persyaratan analisis, dan hasilnya memenuhi persyaratan, langkah selanjutnya adalah pengujian hipotesis penelitian. Uji hipotesis ini dilakukan dengan menggunakan uji kesamaan dua rata-rata satu pihak (pihak kanan) atau uji t (Sudjana, 1992: 470). Untuk distribusi $t_{\text {tabel }}$ pada taraf signifikansi $\alpha=0.05$ dengan $\left(\mathrm{n}_{1}+\mathrm{n}_{2}-2\right)=38$, harga $\mathrm{t}(0.95)$ dapat diketahui $\mathrm{t}_{\text {tabel }}$ adalah 1.68, sedangkan $t_{\text {hitung }}$ dari hasil pengujian diperoleh nilai 2.8. Karena nilai $t_{\text {hitung }}$ lebih besar dari nilai $t_{\text {tabel }}$ maka Ho ditolak. Dengan demikian dapat ditafsirkan bahwa kelompok yang menggunakan pembelajaran gaya mengajar diskoveri ( $\mathrm{x}^{-}=10.05, \mathrm{~s}=6.19$ ) memberikan pengaruh lebih besar dibandingkan dengan kelompok yang menggunakan pembelajaran gaya mengajar komando ( $\mathrm{x}^{-}=$ $7.9, \mathrm{~s}=4.87$ ) terhadap hasil belajar shooting bolabasket.

Hasil perhitungan pengolahan dan analisis seluruh data yang ada, maka hasilnya memberikan jawaban bahwa Pembelajaran dengan menggunakan gaya mengajar diskoveri dapat meningkatkan hasil belajar shooting bolabasket yang lebih besar dibandingkan dengan pembelajaran dengan gaya mengajar komando. Atas dasar itu disarankan untuk meningkatkan hasil belajar shooting siswi SMK dapat digunakan dalam proses pembelajaran penjas., dan hal ini terlihat pada perbedaan dari perhitngan rata-rata, simpangan baku, uji normalitas, uji homogenitas menunjukkan bahwa gaya mengajar diskoveri lebih besar daripada gaya mengajar komando, serta berdasarkan perhitungan uji kesamaan dua rata-rata satu pihak menunjukkan bahwa thitung lebih besar dari nilai t tabel, maka Ho ditolak. Dengan demikian dapat ditafsirkan bahwa kelompok yang menggunakan pembelajaran gaya mengajar diskoveri $\left(\mathrm{x}^{-}=10,05, \mathrm{~s}=6,19\right)$ memberikan pengaruh lebih besar dibandingkan dengan kelompok yang menggunakan pembelajaran gaya mengajar komando $\left(\mathrm{x}^{-}=7,9, \mathrm{~s}=4,87\right)$ terhadap hasil belajar shooting bolabasket.

Berdasarkan hipotesis yang diajukan dalam penelitian ini, pembelajaran dengan gaya mengajar diskoveri memberikan pengaruh yang lebih tinggi dibandingkan dengan gaya mengajar komando terhadap hasil belajar shooting bolabasket. Berarti pembelajaran dengan gaya mengajar diskoveri memberikan pengaruh yang lebih efektif terhadap hasil belajar shooting bolabasket pada siswi kelas XI SMK Pelita Bandung, sehingga dapat dilihat dari penggunaan kedua gaya 
tersebut. Pada pembelajaran dengan gaya mengajar diskoveri menuntut siswa belajar membuat suatu kesimpulan terhadap suatu gerakan shooting dilakukan pada saat situasi dan kondisi yang berubah-ubah, sehingga siswa diberi kebebasan sendiri untuk memutuskan kapan shooting dilakukan, bagaimana teknik gerak shooting dilakukan (saat dijaga oleh lawan yang selalu berubah), jarak dan sudut yang selalu berubah karena lawan yang menjaga. Oleh karena itu, pembelajaran dengan gaya mengajar diskoveri ini dapat dijadikan sebagai acuan strategi pembelajaran untuk menyempurnakan penampilan siswa dalam meningkatkan keterampilan shooting dalam permainan bolabasket. Dengan demikian, pembelajaran dengan gaya mengajar diskoveri memberikan kesempatan pada siswa untuk mempraktikkan, dan mengembangkan performa siswa yang diperlukan berdasar pada tujuan pembelajaran shooting itu sendiri. Penelitian ini membandingkan penelitian sebelumnya yang dilakukan oleh Siregar (2019) dengan judul upaya meningkatkan hasil belajar shooting pada permainan bola basket melalui gaya mengajar komando. Dalam penelitian tersebut menyatakan bahwa Gaya mengajar komando dapat dijadikan sebagai alternative dalam memperbaiki proses belajar terutama proses belajar shooting bola basket. Penelitian tersebut di atas berbeda dengan hasil penelitian ini di mana gaya mengajar komando tidak dapat meningkatkan hasil belajar shooting dalam bolabasket.

Berbeda dengan gaya diskoveri, pembelajaran dengan gaya mengajar komando cenderung menekankan pada perintah atau guru lebih memegang kendali (otoriter) dalam menginstruksikan tugas gerak pada peserta didik. Dengan kata lain, seorang guru akan memberikan pengaruh yang lebih besar dibandingkan peserta didik dalam pemberian informasi. Sehingga pembelajaran dengan gaya mengajar komando digunakan atas dasar bahwa seorang siswa akan dapat lebih mengerti dan memahami apa yang dipelajari dengan melihat dan menyaksikan contoh gerakan yang diperagakan atau dipraktikkan secara langsung oleh guru. Dalam hal ini, siswa harus mengetahui bagaimana gerakan yang harus dilakukan, karena guru hanyalah memberikan contoh-contoh garis besarnya saja. 
Dengan demikian, hal tersebut dapat membedakan bahwa pembelajaran gaya mengajar diskoveri lebih besar pengaruhnya dibandingkan dengan gaya mengajar komando terhadap hasil belajar shooting bolabasket. Hal tersebut dapat disebabkan oleh kurangnya keseriusan sampel dalam mengikuti proses pembelajaran, dan keterbatasn waktu dalam proses pembelajaran serta faktorfaktor lain yang menyebabkan adanya hasil belajar dengan menggunakan gaya mengajar diskoveri dan gaya mengajar komando seperti faktor psikologi, di antaranya tingkat ketegangan dan kemampuan mengatasi tekanan dari dalam diri seperti kecemasan, ambisi, dan emosi ketika melakukan pembelajaran dan tes shooting bolabasket, selain itu tingkat kemampuan belajar dan pengalaman yang berbeda. Hasil penelitian ini pun dapat menjelaskan bahwa pembelajaran gaya mengajar diskoveri dan gaya mengajar komando merupakan suatu cara yang dapat digunakan untuk meningkatkan hasil belajar shooting bolabasket pada siswi kelas XI SMK Pelita Bandung. Namun, peneliti menganjurkan untuk menggunakan pembelajaran dengan gaya mengajar diskoveri, karena pembelajaran dengan gaya mengajar diskoveri memberikan hasil yang lebih besar dalam meningkatkan hasil belajar shooting bolabasket.

\section{SIMPULAN}

Berdasarkan hasil pengolahan dan analisis data, maka dapat disimpulkan hasil penelitian ini adalah pembelajaran dengan gaya mengajar Diskoveri (Kelompok B) memberikan pengaruh yang lebih besar dibandingkan dengan pembelajaran dengan gaya mengajar komando (Kelompok A) terhadap hasil belajar shooting dalam pembelajaran bolabasket di SMK Pelita Bandung. Dari hasil penelitian ini, untuk memperbaiki dan meningkatkan kualitas pembelajaran shooting di SMK, disarankan untuk menggunakan pembelajaran dengan gaya mengajar diskoveri.

Bagi para guru penjas serta pembaca pada umumnya, dalam proses pembelajaran pendidikan jasmani terutama untuk meningkatkan hasil belajar shooting siswa, sebaiknya diberikan gaya mengajar yang lebih sesuai dengan tuntunan dan tujuan pembelajaran berdasarkan kurikulum. Salah satu gaya 
mengajar yang dapat digunakan dalam penjas yang dapat dipilih adalah pembelajaran dengan gaya mengajar diskoveri.

\section{DAFTAR PUSTAKA}

Campbell \& Stanley. (1966). Research learning progrees. USA: Macmilan Publishing.

Husdarta, J., S. (2013). Sejarah dan filsafat olahraga. Bandung: Alfabeta.

Lutan, R. (2000). Strategi belajar mengajar penjaskes. Jakarta: Depdiknas, Ditjen Dikdasmen.

Margono, A. (2010). Permainan bolabasket. Surakarta: UNS press.

Majid, W., \& Roesdianto. (2018). Meningkatkan kemampuan teknik dasar shooting bolabasket menggunakan metode drill. Indonesia performance journal. Universitas Negeri Malang, 2(8).

Nurhasan. (2007). Modul mata kuliah statistik. Bandung: FPOK UPI.

Nurhidayah \& Sukoco, P. (2015). Pengaruh model latihan dan koordinasi terhadap keterampilan siswi ekstrakurikuler bola basket SMPN I Bantul. Jurnal keolahragaan, 3(1), 66-78.

Rubiana, I. (2017). Pengaruh pembelajaran shooting (free throw) dengan alat bantu rentangan tali terhadap hasil shooting (free throw) dalam permainan bola basket. Jurnal siliwangi, 3(2).

Siregar, F., S. (2019). Upaya meningkatkan hasil belajar shooting pada permainan bola basket melalui gaya mengajar komando. Jurnal prestasi, 3(2), 34-41.

Singgih, M., J., P. (2019). Implementasi gaya mengajar discovery untuk meningkatkan keterampilan soccer like games siswa sekolah dasar. Journal of teaching physical education in elementary school, 3(1), 1-7.

Sugiarto. (2019). Pengaruh metode latihan shooting dengan konsep beef terhadap keterampilan shooting freethrow bola basket pemula. Jurnal SPEED, 2(2).

Sugiyono. (2012). Statistika untuk penelitian. Bandung: PT Alfabeta.

Yulidasari, R. (2015). Variasi latihan teknik shooting bolabasket siswa peserta ekstrakurikuler di SMPN 22 Malang. Jurnal pendidikan jasmani, 25(1). 